\title{
Role Of Motivational Factors In The Development Of Profession As A Teacher
}

\author{
Ishtiaq Hussain, Kohat University (KUST), Pakistan \\ Hafiz Inamullah, Kohat University (KUST), Pakistan \\ Muhammad Naseer-Ud-Din, Kohat University (KUST), Pakistan \\ Falak Naz, Female District Education Officer (Elementary), Pakistan \\ Muhammad Naeem Butt, Kohat University (KUST), Pakistan
}

\begin{abstract}
The main objective of this study was to identify the motivational factors in selecting a teaching profession by the teachers. A random sampling technique was used for the selection of the sample consisting of 27 girls' schools of District Kohat as the sample. A structured questionnaire was developed in closed format on the basis of factors identified through observation by the teachers. The data collected through the questionnaires about various aspects of the study were presented in percentages in tabular form and applied to a Chi-square test.
\end{abstract}

Keywords: motivational factors, teaching profession, Secondary schools, structured questionnaire, closed format, observation, percentages

\section{INTRODUCTION}

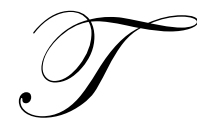

eachers play the most important and practical role in education. They are said to be the builders or architects of a nation. The teacher is the central log in the educational system and the quality and worth of teachers determines the quality of education. Teaching facilitates learning, which is a complex phenomenon that has been explained differently (Slavin, 1947).

Over a long period of the past, educational psychology has used a variety of approaches to explain the concept of learning. There are four approaches to explain learning, which include behavioral approach, cognitive approach, social learning approach, and humanistic approach. Though the cognitive approach to explain learning is very popular today, the behavioral approach has much to contribute to the practice of education (Crowk, 1997).

\section{REVIEW OF RELATED LITERATURE}

"And he taught Adam the nature of all things. Then he placed them before the Angles, and said, tell me, the nature of these if you right", They said; Glory to thee of knowledge we have non, save what thou hast taught us in truth it is thou who are perfect in knowledge and wisdom" (Ali, 1934).

The committee on National Education 1959 has highlighted the role of teacher in the system of education in these words, "No system of education can rise above the teachers who serve it, and its quality depends ultimately on the quality and efforts of the teacher" (Government of Pakistan, 1959).

In the view of Imam Abu Hanifa, a teacher should be like a father - well versed in the psychology of children treating them with love and affection. There should be no inconsistency between his word and deed.

Ghazali believes that to teach is to worship. He who pursues learning in order to make money, attain social position, escape his obligations towards the Sultan or for sake of any other ambition save that of serving Allah, exposes himself to dire consequences. 
A teacher affects eternity; he can never tell where his influence stops (Henry Adams).

He who opens a school door closes a prison (Victor Hugo).

The teacher is more important than what he teaches (Karl Manager).

\section{IDENTIFICATION AND CATEGORIZATION OF FACTORS}

On the basis of examination of related literature about the motivational factor in selecting teaching profession, a list of factors have been identified like, Attractive Factors, Economic Factors, Family Profession, Religious Factors, Social Factors and Intrinsic Factors.

\section{RESEARCH METHODOLOGY}

The study was conducted on opinion survey method. The motivational factor in selecting teaching profession was the main focus of the study. The factors that may lead to selecting a teaching profession were identified in a questionnaire.

\section{ANALYSIS OF DATA AND RESULTS}

The information collected through the questionnaire about various aspects of the problems was tabulated. The responses were analyzed and presented in percentage form. Collected data were tabulated of 27 Girls High and Girls Higher Secondary schools of Kohat District. The total of respondents was 81 . 1 below:

Distribution of respondents according to their academic and professional qualification is presented in Table

Table 1

Distribution of respondents according to academic and professional qualification

\begin{tabular}{|c|l|c|c|}
\hline S.No & Academic \& Professional Qualification & No. of Teachers & Percentage \\
\hline 1 & B.A, B.Ed & 29 & $39.80 \%$ \\
\hline 2 & BSc, BEd & 15 & $18.52 \%$ \\
\hline 3 & M.A, BEd & 20 & $24.69 \%$ \\
\hline 4 & MSc, BEd & 02 & $02.47 \%$ \\
\hline 5 & M.A, M.Ed & 04 & $04.93 \%$ \\
\hline 6 & BSc, MA, B.Ed & 03 & $03.70 \%$ \\
\hline 7 & B.S.Ed & 02 & $02.46 \%$ \\
\hline 8 & M.A Edu & 02 & $02.46 \%$ \\
\hline 9 & B.A B.Ed, M.Ed & 02 & $02.46 \%$ \\
\hline 10 & BSc, B.Ed, M.Ed & 02 & $02.46 \%$ \\
\hline
\end{tabular}

The data showed that 39.80 percent of the teachers were B.A, B.Ed. The second largest group was with the percentage of 24.69 M.A, B.Ed The group of teachers at Sr. No. 4,7,8,9,10 were just $2.46 \%$, each having the qualification of MSc, B.Ed, BS, B.Ed, MA Education, BA, BEd, MEd, and BSc, BEd, M.Ed, respectively.

\section{CONCLUSIONS}

1. Most of the teachers responded that they adopted this profession because it is an easy way to earn money (salary + tuition) and respect. They can enjoy a number of holidays; i.e., Summer Vacations, Winter, Spring and other gazetted holidays.

2. It was concluded that majority of the teachers were accidental. When they did not get proper chance in any job, they decided it is better to serve the nation. 
3. Teaching is a task of give and take. In this way the teachers got real satisfaction by enhancement of knowledge and continue their studies keeping in view that it is profession of Prophethood as well as development of the Islamic society.

\section{RECOMMENDATIONS}

The researchers now make the following recommendations in the light of findings of the study for making the teaching profession more attractive for the prospective teachers.

1. Mostly the talented persons do not want to join the teaching profession because there is too little pay and low social status in it. If these two things are removed, the attitude of those who dislike teaching may be changed for the better people as well.

2. The Commission on National Education 1959 has already made sound recommendations for increasing the pay and raising the prestige of teaching professions. If they are implemented, it is great hope for a better situation.

3. Salary scales for teachers should be revised according to their performance in curricular, as well as cocurricular activities, cooperation with staff, and keeping in view the annual reports (ACRs) of the teachers.

4. The teacher is considered to be a model in the educational system. The government should organize refresher courses, speeches, articles, seminars, workshops and conferences to modify the attitudes of the teachers at different intervals.

\section{AUTHOR INFORMATION}

Dr. Ishtiaq Hussain, Ph.D in Education. He is working as Director of Institute of Education and Research in Kohat University, Pakistan.

Dr Hafiz Inamullah, Assistant Professor Kohat University of science and Technology, Kohat, Pakistan.

Dr Muhammad Naseer-Ud-Din, Assistant Professor Kohat University of science and Technology, Kohat, Pakistan.

Dr.Falak Naz, Female District Education Officer (Elementary), Rawalpindi, Pakistan.

Muhammad Naeem Butt, Kohat University of Science and Technology, Pakistan.

\section{REFERENCES}

1. Ali, Y. (1934), The Holy Quran, Text Translation and Commentary, Vol. 1, Kashmiri Bazaar, Lahore, Pakistan.

2. Cole, L. (1950), A History of Education, New York: Bin hart and Company.U.S.A.

3. Govt of Pakistan: Ministry of Education (1959), Report of Commission on National Education, Karachi, Pakistan.

4. Musuarat. A, (1962), "Education in Pakistan" AIOU. Symaz Printer Karachi, Pakistan.

5. $\quad$ Super, D. (1957), The Psychology of Careers, New York: Harper \& Brothers, Ltd.U.S.A. 
NOTES 